\title{
EXPERIENCE AND INFORMATION SEARCH PATTERNS IN COMPLEX DECISION MAKING
}

\author{
Vladimír BALÁŽ ${ }^{1,2}$, Viera BAČOVÁ ${ }^{1,3}$, Pavel ŠKRINIAR ${ }^{4}$ \\ ${ }^{1}$ Institute of Experimental Psychology, Slovak Academy of Science \\ Dúbravská cesta 9, 84104 Bratislava, Slovak Republic \\ ${ }^{2}$ Institute for Forecasting, Slovak Academy of Sciences \\ Šancova 56, 81105 Bratislava, Slovak Republic \\ E-mail:vbalaz@yahoo.com \\ 3 Institute of Applied Psychology \\ Faculty of Social and Economic Science, Comenius University in Bratislava \\ Mlynske luhy 4, 82105 Bratislava, Slovak Republic \\ E-mail: viera.bacova@fses.uniba.sk \\ ${ }^{4}$ Department of Business Finance \\ Faculty of Business Management, University of Economics in Bratislava \\ Dolnozemska 1, 85235 Bratislava, Slovak Republic \\ E-mail: pavel.skriniar@euba.sk
}

\begin{abstract}
This study focused on issues of information search patterns and the ways individuals use to reduce complexity of decision and form judgment on alternatives under conditions of incomplete information. The aim was to determine whether and how participants with a financial and migration experience differ from participants without this experience in acquiring and ordering information prior to choice of financial products and labor migration destination. The authors examined amount and content of information which were requested by participants in model decision tasks. Perceived expertise and experience seemed important for learning and reducing information overload. Considerable stability of preferences in decision tasks with limited and unlimited access to information was found. In pre-decisional information search dominant attributes were coming in pairs, where the first attribute related to major advantages and the second one to major costs of the potential outcomes both in financial and migration decision tasks.
\end{abstract}

Key words: information search patterns, experience, decision making

\section{INTRODUCTION}

Complex decisions typically involve high number of alternatives, intricacy and large amount of decision attributes and uncertain

This work was supported by the Slovak Research and Development Agency under the contract No. APVV-0361-12. outcomes (Payne, 1976). However, acquisition of information for judgment of alternatives is not costless and at some point the marginal utility of additional information is lower than its cost. In real world some information is not available to a decision-maker at all and complex decisions are often taken under the type of choice or task condition with incomplete or missing information.

DOI: 10.21909/sp.2014.01.647 
The economic theory assumes that a good decision is an informed one. A rational decision-maker makes his/her choice after learning all the relevant facts about the focus of the decision. Researchers, however, have already widely acknowledged the fact that human decisions are constrained by limited processing capacity of the human brain (Simon, 1978; Kahneman, 2003). Cognitive burden may be significant and the decisionmaker has to make trade-offs between choice accuracy and efforts spent (Payne, Bettman, Johnson, 1993). Attention is a scarce resource and must be deployed in frugal and efficient ways. Research studies on complex choices have indicated that individuals tend to apply a wide repertoire of heuristic strategies to reduce the complexity of the task (Bettman, Luce, Payne, 1998). The complexity of the task may force the decision-maker to use only a part of the available information and judgment formation takes place under incomplete information. Incomplete information increases the uncertainty of the outcome of the decision. As to decreasing the uncertainty, the decision-maker has to decide either to use surrogate missing information or ignore it.

Not all information is considered equally useful by a decision-maker. Some information is considered more important than and accessed prior to other information. Prioritization of certain kind of information may result from a decision-maker's preferences, attitudes and beliefs. The normative economic theories of decision-making assume that individual preferences over consumer goods and services are innate, consistent and revealed during the choice process (von Neumann, Morgenstern, 1944). Psychology demonstrated ample evidence on adaptive decision-making and preference reversal. It led to the conclusion that preferences are not revealed but constructed during the decision-making process (Bettman et al., 1998; Lichtenstein, Slovic, 2006). As noted by Warren, McGraw, van Boven (2011, p. 194) conclusions concerning constructed preference 'can range from the more conservative observation' that 'consumers may lack a well-defined preference structure' to the slightly more ambitious claim that 'preferences are often constructed' (Slovic, 1995) to the more extreme belief that 'choice is inherently constructive' (Bettman et al., 1998). In contrast, some psychology theorists challenged the idea that preferences are always or even usually constructed and proposed that many decisions may stem from stable, underlying preferences (Kivetz, Simonson, 2000; Simonson, 2008). Warren et al. (2011) suggested that preferences are rather calculated than constructed. Calculation means that the decision-maker may form judgments and decisions via integration of various pieces of information retrieved both from memory and the type of choice or task condition. Calculation may yield preferences that appear stable over diverse decision type of choice or task condition, but diverse type of choice or task condition may also generate retrieval of discrepant preferences. The extent to which preferences are calculated can be guided by goals, cognitive resources and experience of a decision-maker.

As for the sequence for information processing, Huber et al. (2011) formulated the 'advantage first' principle. The principle holds that decision makers initially seek and process information about positive consequences and subsequently concentrate further elaboration of the mental representation on those alternatives that prove to be promising after the first evaluation. Later, a more 
detailed analysis may focus on potential negative outcomes, probabilities, or additional actions that could neutralize risks related to the alternative.

Difficulty of the task and preference of particular attributes may be impacted by the degree to which the decision attributes are accessible to a decision-maker. Abstract and/ or previously unknown problems may be more difficult to analyze as those, where decision attributes are more easily imaginable and comprehensible. Would the information search patterns and judgment formation be similar or different in the two types of decision problems? The research design included two diverse domains of economic decision problems. The first task modelled decisions on purchase of complex financial products. The second task modelled choice of potential destination for labor migration. Both the purchase of financial products and decisions on international labor migration are difficult cognitive tasks with potentially great consequences for the decision-maker. They account for uncertain outcomes and usually involve large amounts of information search and processing.

This research study focused on the issues of information search patterns, information overload and the ways by which individuals reduce the complexity of the decision tasks and form judgments on alternatives under conditions of incomplete information. How does the decision-maker settle with a comprehensive choice? How does s/he progress in acquiring, ordering and searching through information before a choice is made? Although personal characteristics (for example, personal need for structure, among many others) undoubtedly play an important function in these processes, we focused on the strategy of acquiring and organizing infor- mation and the process of learning in the research tasks.

The research aim was to determine whether and how decision-makers with a financial and migration experience differ from those without these experiences in acquiring and ordering information prior to the choice of financial products and labor migration destination. Under the migration experience we understood a voluntary stay abroad for at least 6 months in order to study (scholarship program, language courses) or work, respectively, a summer job. As the level of financial expertise was not possible to determine in a similar objective way, we used a self-assessment of skills in the financial field for the purpose of this study.

In this research study, we also focused on pre-decisional acquiring information in the two types of choices: the binary and the complex choice tasks. As we did not expect differences between men and women in these cognitive processes, we explored the differences between experts/experienced participants and non-experts/participants without migration experience. However, we were checking the impact of gender as well.

As indicators for finding information were considered a) amount of information which the participant requested about attributes of alternatives in the two decision-making tasks (in the binary choice and the complex choice); b) attributes the participants asked for the most, i.e., dominant attributes (in the binary choice and the complex choice).

We formulated the following seven research hypotheses for both domains of the decision: financial products and labor migration:

$\mathrm{H} 1$ : Decision-makers will try to minimize the cognitive burden and limit the amount of information in the complex choice. 
$\mathrm{H} 2$ : Repeated decision-making on the same subject will be assisted by the learning process. The learning process will be reflected in the decreasing amount of information accessed.

H3: The amount of information search will be assisted by perceived expertise and/or experience. More experienced participants will request less amount information than non-experts/less experienced ones.

H4: Participants with higher expertise/experience will learn the task faster and account for a more curvilinear learning curve than participants with lower expertise/experience.

$\mathrm{H} 5$ : Prioritized attributes (preferences) will remain the same in the binary and the complex choice.

H6: Participants with higher expertise/experience will assign different importance (decision weights) to particular attributes of alternatives compared to the non-experts/less experienced participants.

H7: The 'advantage first' principle will apply in the pre-decisional judgments: participants will ask about beneficial attributes of decision outcomes first, and concentrate on the negative ones later.

\section{METHOD}

\section{Participants}

The sample included 220 participants, university undergraduates and post-graduates (115 women and 105 men; average age 27.1 years) in the decision making task on financial products and 157 participants ( 79 women and 78 men; average age 25.4 years) in the decision making task on migration. All participants who made decisions on the migration tasks took the financial products decision task as well.
The sample of 157 participants, who made decision tasks on labor migration, was wellbalanced in terms of experience with international migration and gender. It consisted of 80 participants with migration experience (41 women and 39 men) and 77 without migration experience ( 38 women and 39 men).

Participants were asked to self-assess their financial knowledge on a scale ranging from 0 "no knowledge" to 10 "I am a real financial expert". Sixty two participants $(28.2 \%)$ indicated knowledge on levels 6-10 and were considered experts, while the rest (158 participants, $71.8 \%$ ) indicated knowledge on levels 0-5 and were considered non-experts.

Only 28 out of 115 women, but 34 out of 105 men identified themselves as experts. In our sample men accounted for higher levels of perceived expertise in financial products than women (Cramer's V $=0.089$, sig. 0.008). A representative survey of financial literacy in the Slovak population found a) generally low levels of financial literacy in general and by women respondents in particular, and b) strong correspondence between actual and perceived financial literacy (Baláž, 2012).

The sample structure was aimed at minimizing socio-demographic variations within the sample. Age and education profile of the sample was important for research on migration decisions (as most Slovak migrants move abroad at the age of up to 35) and purchase of complex financial products (as educated people tend to have higher income and better understanding of financial products and markets).

\section{Tasks Structure}

In the decision making task on financial products, the participants were presented with the following hypothetical task: 
'Please imagine, you have 10000 euros ${ }^{1}$. We offer you various types of investments. You can ask for information on eight investment attributes: risk level, annual return, entry fee, optimal investment horizon, condition of access to money (with no penalty paid), annual fees, exit fees and names of financial institutions. Please consider the available information and tell us, which product you would invest in.'

Recording sheets included real financial products offered on the Slovak financial market in 2012. In selected cases we replaced names of actual financial institutions with invented ones, as to examine the potential impact of institution's image on investment decisions. Range of investments included low-risk products (term deposits in banks and money market funds, essentially 'safe options'), medium risk products (pension funds and investment life insurance) and high-risk products (stock market funds) (see Appendix for more details).

In the decision making task on labor migration destination participants were presented with the following hypothetical task:

'Please imagine, you graduated from a University and found work with a multinational company which has branches around the world. You are offered an opportunity to obtain a good job and career advancement. Your employer, however, indicates that you would have to accept a company transfer to a foreign country for three years. You may choose from 10 countries. The job position (business representative) is the same in whichever country you choose. You are expected to learn the basics of the local lan-

\footnotetext{
${ }^{1}$ Investment of 10000 euros roughly equalled
} two annual median net wages in Slovakia in 2011. guage in one year. Extra pay will be received for working in 'demanding' countries.'

Participants could request information from a researcher on the following eight attributes of migration destination: a) monthly net wages in euros; b) monthly living costs in euros ${ }^{2}$; c) climate conditions; d) crime rates (based on homicide rate statistics, UNODC 2011); e) health risks (based on recommendations by the World Health Organization 2012); f) language difficulty; g) degree of life satisfaction (based on the Life Satisfaction Index, White 2007), and h) degree of personal freedom and security (based on the Civil Liberties Index, Freedom House 2012).

Except for data on wages and living costs, data for all other variables were rescaled to a six point scale. The scale for negative attributes (health risk, crime rate, language difficulty) was: very low, low, medium-low, medium-high, high, very high. Positive attributes (life satisfaction, freedom and security) were ranked on a reversed scale (examples of recording sheets are provided in the Appendix).

The design of both decision tasks was adapted from Monti et al. (2009) study of complex financial decision making. Judgment formation and decision-taking were examined in two different types of choices - the binary choice and the complex choice. The type of choice differed also in the access to information. In the condition of the binary choice, participants chose from two unla-

\footnotetext{
${ }^{2}$ Original data on wages and living costs were taken from information provided by the International Labour Organisation statistics (ILO 2010). Data were slightly manipulated in such a way, as to allow the employers to reward their employees for working in some of the poorer, more 'difficult' countries (creating a form of risk premium)
} 
beled financial products or two unnamed countries. They could obtain half of the total available information (eight attributes of two products/countries $=16$ information units). Quantitative limits imposed on available information (8 information units as a maximum) simulated the type of choice or task condition with costly information (Stigler, 1961) and helped to identify information considered most important by the participants. The trial was repeated four times with different pairs of unnamed financial products and countries (trials i- iv). Names of the products/countries were not revealed as to separate the potential impact of image from impact of task structure on the choice. The data collectors recorded the order of information asked for, and the total amount of information requested across trials $\mathrm{i}-\mathrm{iv}$.

In the condition of complex choice, the decision set contained 15 financial products with 8 attributes (120 information units in total), and 8 migration attributes for 10 countries ( 80 information units in total). The complex choice type of choice or task condition accounted for significant information processing costs. Participants were allowed to request any number and type of information before making their choice. The trial was repeated four times with different sets of products and countries (trials 1-4). At the end of the task, participants were ask to choose one out of 15 financial products and rank 10 countries on a scale 1 (best countries) to 10 (worst destination), respectively.

\section{Procedure}

The Active Information Search (AIS) method was used for presenting and the manual version of the Mouselab method for recording the data. In the Mouselab method
(Reisen, Hoffrafe, Mast, 2008, p. 642) participants use a computer mouse to click on or move a cursor over the cells of an information matrix. The Mouselab method provides detailed records on information acquisition in terms of orders of cells examined and time spent looking at each cell. The Mouselab, however, presents the information overly structured. A participant can see the screen and understand the structure of information in advance instead of creating this structure by him/herself. In real life information comes mostly unstructured. The AIS is based on interactive dialogue with the participants. This format is closer to real life, as people often learn important information via talking to their friends, peers or experts. Major shortcoming of the AIS is its time consuming nature (Huber, Wider, Huber, 1997). An average interview took 2-3.5 hours in our research. Each interview finished with a question on the most important factors for making the final decision on a purchase of a financial product or ranking migration destinations. The Short Retrospective Verbal Protocol (RVP) was taken immediately after task completion.

\section{RESULTS}

\section{FINANCIAL PRODUCTS}

\section{The Amount of Information Requested and Learning}

Fourteen out of 220 participants $(6 \%)$ asked for all available information (120 units) in the complex decision task. The number of participants using limited information increased over trials i - iv. Less than 30 units (one quarter) of total available information were requested by $38.2 \%$ of par- 
ticipants in trial 1 , but $64.1 \%$ of participants in trial 4.

The average amount of information requested had decreased from $39.6 \%$ in trial i to $27.0 \%$ in trial iv. The decrease was statistically significant for each shift over trials i to iv (Wilcoxon test; sig. $=0.0001$ ). The decreasing amount of information needed for making a decision on the purchase of a financial product we ascribe to the learning effect. The participants constructed and/or affirmed their preferences and became able to conclude their decisions with lower information burden.

Experts asked for less information than non-experts in each of the four trials, and the non-experts accounted for a more linear learning curve (Figure 1). The number of information units requested between trials 1 and 2 declined from 48.4 vs. 41.2 units for non-experts (Wilcoxon test sig. 0.0001) and 45.4 vs. 36.8 units, for experts (sig. 0.066). Between

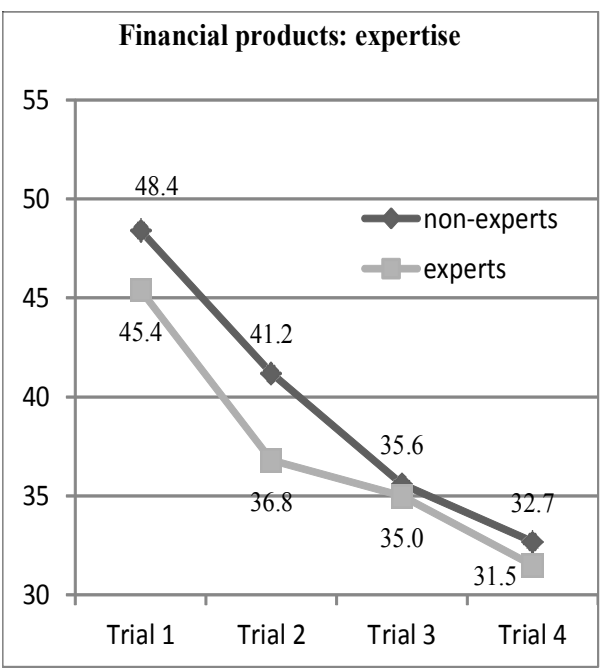

Figure 1. Information units requested in complex choice by financial expertise trials 2 versus 3 the number of information units decreased from 41.2 to 35.6 units for non-experts (sig. 0.002), but only from 36.8 to 35.0 units for experts (sig. 1.000). Finally, the number of information units requested between trials 3 and 4 dropped from 35.6 to 32.7 units for non-experts (sig. 0.021) and 35.0 to 31.5 units for experts (sig. 0.067). Experts seemed to learn most in the early trials, while the learning curve for non-experts was more linear.

The Wilcoxon test was applied to examine the differences in the learning curve for men and women, and experts and non-experts. Men consistently demanded more information than women over trials $1-4$. In the case of men, the number of information units decreased from 50.6 to 41.6 between trials 1 and 2 (sig. 0.0001 ), from 41.6 to 37.0 between trials 2 and 3 (sig. 0.023), and 37.0 to 33.9 between trials 3 and 4 (sig. 0.057). As for the women, the number of information units dropped from 44.8 to 38.5 between trials 1 and 2 (sig. 0.002 ), from 38.5 to 34.0 between trials 2 and 3 (sig. 0.171), and 34.0 to 31.0 between trials 3 and 4 (sig. 0.027). The learning curve was more linear for the women compared to the men in the decision task on financial products (Figure 2).

Men seemed to learn to reduce the information burden faster than women and nonexperts faster than experts, but the MannWhitney U-test found no significant difference for gender and experts/non experts in the number of information units requested in trials $1-4$. In the latest trials, the amount of information requested almost converged for both gender and experts/non-experts (Figure 1). As men declared higher expertise in financial products than women, it may explain why more linear learning curves were found both for women and non-experts. 


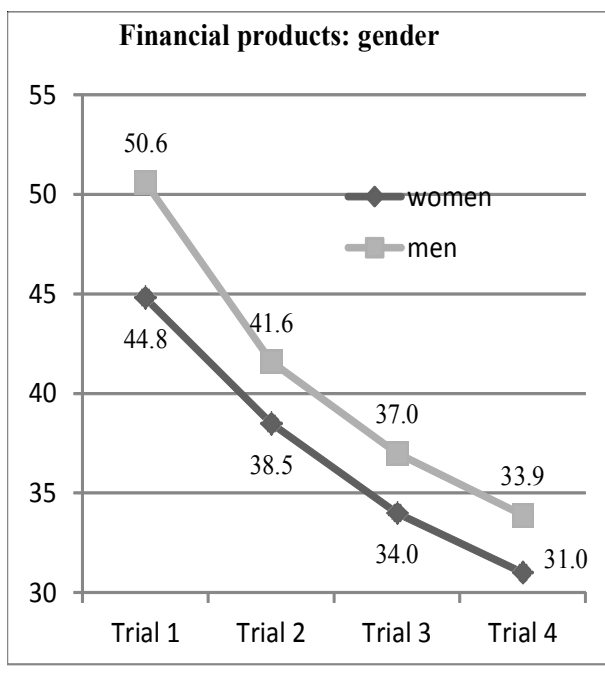

Figure 2. Information units requested in complex choice by gender

Dominant Attributes (Preferences) in Decision Making on Financial Products

In the binary choice (with limited access to information), return and risk proved to be the dominant attributes for judgment of options and were requested in $82.7 \%$ and $81.0 \%$ of cases, respectively. Information on annual fees $(50.3 \%)$, optimal investment horizon $(44.5 \%)$, entry fee $(40.9 \%)$, access to money $(40.6 \%)$, bank name $(27.5 \%)$ and exit fee $(21.9 \%)$ was requested less frequently. The rank of attributes by frequency of information requested changed little over trials $1-4$ (Table 1).

In the complex choice (with non-limited access to information) return $(89.4 \%)$ and risk $(82.6 \%)$ again were dominant attributes, followed by annual fees $(67.7 \%)$, entry fee $(60.7 \%)$, bank name $(55.0 \%)$, access to money (54.9\%), optimal investment horizon (54.3\%) and exit fee (49.1\%). The rank of attributes by frequency of information requested again changed little over trials $1-4$ (Table 1).

The ordering of the criteria for judgment of options is considered to be an expression of preferences. The similarity of attribute ranking in the binary and complex choices indicated considerable stability of preferences by the participants, under diverse

Table 1. Percentage of accessed information for particular financial products in the binary and complex choices $(\mathrm{N}=220)$

\begin{tabular}{|l|c|c|c|c|c|c|c|c|}
\hline $\begin{array}{l}\text { Financial } \\
\text { Products }\end{array}$ & Risk & Return & $\begin{array}{c}\text { Entry } \\
\text { Fee }\end{array}$ & $\begin{array}{c}\text { Optimal } \\
\text { Horizon }\end{array}$ & $\begin{array}{c}\text { Access to } \\
\text { Money }\end{array}$ & $\begin{array}{c}\text { Annual } \\
\text { Fee }\end{array}$ & $\begin{array}{c}\text { Exit } \\
\text { Fee }\end{array}$ & Bank \\
\hline \multicolumn{7}{|l|}{ Binary choice } \\
\hline Trial i & 81.8 & 88.6 & 45.0 & 46.4 & 43.6 & 54.1 & 26.8 & 23.2 \\
\hline Trial ii & 79.1 & 80.9 & 43.2 & 45.9 & 38.2 & 49.1 & 22.7 & 26.8 \\
\hline Trial iii & 80.9 & 80.0 & 39.5 & 41.4 & 43.2 & 50.5 & 19.1 & 30.0 \\
\hline Trial iv & 82.3 & 81.4 & 35.9 & 44.5 & 37.3 & 47.7 & 19.1 & 30.0 \\
\hline Average & 81.0 & 82.7 & 40.9 & 44.5 & 40.6 & 50.3 & 21.9 & 27.5 \\
\hline Complex choice & 89.1 & 93.6 & 64.5 & 64.1 & 61.8 & 71.8 & 52.3 & 57.3 \\
\hline Trial 1 & 89.8 & 51.4 & 58.6 & 56.4 & 54.5 & 66.8 & 50.5 & 56.8 \\
\hline Trial 2 & 86.8 & 91.5 & 54.5 & 70.5 & 44.5 & 59.1 \\
\hline Trial 3 & 78.6 & 89.1 & 62.3 & 48.6 & 54.5 & 61.8 & 49.1 & 60.0 \\
\hline Trial 4 & 75.9 & 83.6 & 57.3 & 48.2 & 48.6 & 67.7 & 49.1 & 58.3 \\
\hline Average & 82.6 & 89.4 & 60.7 & 54.3 & 54.9 & 67.7 \\
\hline
\end{tabular}


modes of access to information (limited versus unlimited) and choice size (two versus 15 financial products). With ongoing trials, the amount of requested information was decreasing, however the type of information required (dominant attributes) was not changing.

Information search patterns for two dominant attributes followed the logic of the 'advantage first' principle. Out of 880 total searches, in the binary choice return was the first request in 289 searches and risk the second request in 239 searchers. Out of the same number of searches, in the complex choice return was the no. 1 question in 296 and risk no. 2 question in 226 searches.

Impact of gender and perceived expertise on information search patterns was analyzed via the Mann-Whitney U-test. We examined whether the participant requested information on a particular attribute or not. In the binary choice (trials $\mathrm{i}-\mathrm{iv}, \mathrm{N}=4$ × $220=880$ ), only one difference between men and women was found. Men requested more information on return than women (sig. 0.002).

In the complex choice, men requested more information on entry and exit fees than women (sig. 0.005 and 0.0001, respectively). Women, on the other hand, were more interested in the name of the financial institution than men (sig. 0.0001).

As for the perceived expertise, only one significant difference was found: participants with lower perceived expertise were more interested in risks related to the investment (sig. 0.006). No significant difference was found for experts and non-experts in terms of the amount of information required for a particular attribute.

Gender differences in information search patterns were closely related and intertwined with the differences in perceived expertise.
Men accounted for higher levels of perceived expertise in financial products than women, however, we can assume they also had higher actual expertise, as they requested more information on fees related to investments than women did (fees may heavily impact returns on financial investments). Women, on the other hand, were more interested in the name of the financial institution. Bank name awareness probably surrogated actual financial expertise in women.

\section{LABOR MIGRATION}

\section{The Amount of Information Requested and Learning}

Similarly to the decision task on financial products, 13 participants $(8.3 \%$ out of 157$)$ requested all available information about the destination for labor migration. The overall amount of information decreased rapidly over trials $1-4$. Less than one quarter of the total of the available information (20 units) was requested by some $25.5 \%$ of participants in trial 1 , but $41.4 \%$ of participants in trial 4 . The decrease was statistically significant for trials 1 versus 2 (Wilcoxon test, sig. 0.0001), and trials 2 versus 3 (sig. 0.017 ) but not for trials 3 versus 4 (sig. 0.112). The learning effect was the greatest in the earlier trials.

The Mann-Whitney U-test found no significant differences in the number of information units requested by gender and migrants/non-migrants over trials $1-4$. To examine the process of learning, we used the Wilcoxon sign test t. Men and women accounted for quite similar slopes of the learning curves (Figure 3 ). The number of information units decreased from 34.8 to 31.5 for men (sig. 0.0001) and 37.7 to 33.5 for women (sig. 0.011) between trails 1 and 2. Between 


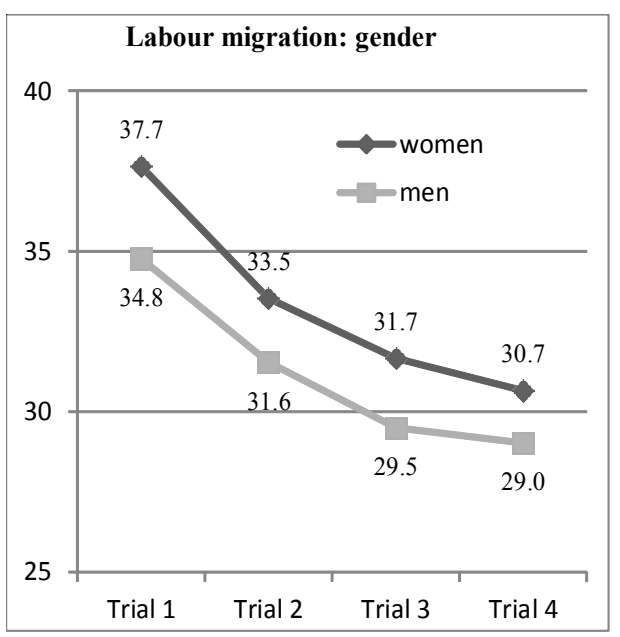

Figure 3. Information units requested in complex choice by gender

trials 2 and 3, the number of information units dropped from 31.5 to 29.5 for men (sig. 0.091) and 33.5 to 31.7 for women (sig. 0.097). The drop in the number of information units used was insignificant between trails 3 and 4: from 29.5 to 29.0 for men (sig. 0.336) and 31.7 to 30.7 for women (sig. 0.154).

Migrants and non-migrants accounted for a steeper drop in the number of information units demanded between trials 1 and 2 (34.6 versus 30.8 units, Wilcoxon test sig. 0.015; 37.9 versus 34.4 units, sig. 0.0001 , respectively) (Figure 4). Between trials 2 versus 3 , the number of requested information units declined from 34.4 to 32.4 for non-migrants (sig. 0.035), but only from 30.8 to 28.9 units for migrants (sig, 0.213). The decline in the number of information units demanded was insignificant for both groups between trials 3 and 4 (from 32.4 to 32.0 for non-migrants, sig. 0.498 , and 28.9 to 27.8 for migrants, sig. $0.125)$.

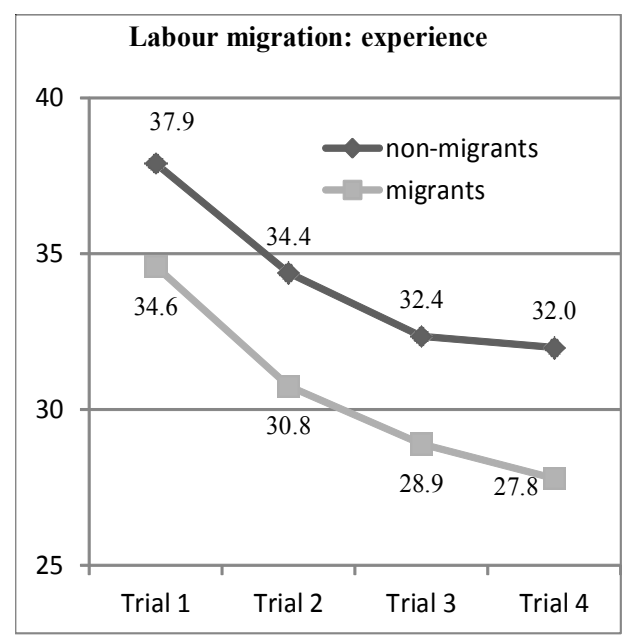

Figure 4. Information units requested in complex choice by migration experience

The sample was well-balanced in terms of international migration experience and gender: it consisted of 80 migrants (41 women and 39 men) and 77 non-migrants (38 women and 39 men). Since the learning curve had a similar slope for men and women but was more curved for non-migrants than migrants, the migration experience was likely of higher importance for the learning rate than gender. We assume that migrants asked for less information in the earlier trials as they could draw on their migration experiences and identify information relevant for migration better than non-migrants (Figure 3 and 4).

\section{Dominant Attributes (Preferences) in Decision Making on Migration Destination}

In the binary choice (with limited access to information), monthly wages and costs of living proved dominant attributes and were 
Table 2. Percentage of accessed information for particular migration attributes in the binary and complex choices $(\mathrm{N}=157)$

\begin{tabular}{|l|c|c|c|c|c|c|c|c|}
\hline $\begin{array}{l}\text { Labor } \\
\text { Migration }\end{array}$ & $\begin{array}{c}\text { Health } \\
\text { Risks }\end{array}$ & Language & $\begin{array}{c}\text { Freedom } \\
\& \\
\text { Security }\end{array}$ & Wages & $\begin{array}{c}\text { Crime } \\
\text { Rate }\end{array}$ & $\begin{array}{c}\text { Life } \\
\text { Satisfaction }\end{array}$ & Climate & $\begin{array}{c}\text { Living } \\
\text { Costs }\end{array}$ \\
\hline \begin{tabular}{l} 
Binary choice \\
\hline Trial i
\end{tabular} 49.7 & 52.2 & 38.9 & 86.0 & 40.1 & 32.5 & 26.1 & 87.9 \\
\hline Trial ii & 51.0 & 45.2 & 45.9 & 84.7 & 46.5 & 36.3 & 28.7 & 77.1 \\
\hline Trial iii & 41.4 & 42.7 & 43.3 & 87.3 & 46.5 & 45.2 & 29.9 & 79.0 \\
\hline Trial iv & 44.6 & 45.2 & 50.3 & 86.6 & 42.7 & 42.7 & 29.9 & 76.4 \\
\hline Average & 46.7 & 46.3 & 44.6 & 86.1 & 43.9 & 39.2 & 28.7 & 80.1 \\
\hline Complex choice & \multicolumn{7}{|l|}{} \\
\hline Trial 1 & 55.4 & 33.8 & 53.5 & 93.6 & 59.9 & 48.4 & 17.8 & 88.5 \\
\hline Trial 2 & 51.6 & 28.0 & 47.8 & 89.8 & 58.0 & 43.3 & 15.3 & 83.4 \\
\hline Trial 3 & 45.9 & 26.8 & 46.5 & 83.4 & 54.1 & 44.6 & 14.0 & 78.3 \\
\hline Trial 4 & 48.4 & 24.2 & 44.6 & 79.0 & 54.8 & 43.9 & 14.0 & 74.5 \\
\hline Average & 50.3 & 28.2 & 48.1 & 86.5 & 56.7 & 45.1 & 15.3 & 81.2 \\
\hline
\end{tabular}

requested in $86.1 \%$ and $80.1 \%$ of cases, respectively. Information on other attributes was requested less frequently, namely health risks (46.7\%), language difficulty (46.3\%), freedom and security $(44.6 \%)$, crime rate $(43.9 \%)$, life satisfaction $(39.2 \%)$ and climate (28.7\%) (Table 2).

In the complex choice (with non-limited access to information) wages $(86.6 \%)$ and living costs $(81.2 \%)$ again were dominant attributes, followed by crime rate $(56.7 \%)$, health risks $(50.3 \%)$, freedom and security (48.1\%), life satisfaction (45.1\%), language difficulty $(28.2 \%)$ and climate $(15.3 \%)$. The rank of attributes by the amount of information requested did not change over trials $1-$ 4 and was similar to that in the binary choice condition. The only important difference for attribute ranking in the two-task condition was related to language difficulty. The difference is explained by the fact that country names were hidden in the binary choice, but revealed in the complex choice tasks. With country names stated in the complex choice condition, the participants usually did not need to ask about language difficulty. Information on language difficulty was requested only for some countries less-known to the participants (e.g., Taiwan or Iran) (Table 2).

Information search patterns for dominant attributes were in line with the assumption about the "advantage first principle". In the binary choice, wage was the no. 1 question in 276 , and living costs the no. 2 question in 238 searchers, out of 880 total. In the complex choice, wage was the no. 1 question in 372 , and living costs the no. 2 in 314 searches, out of 880 total.

In the binary choice, the Mann-Whitney U-test indicated that women requested more information on some negative attributes of migration than men, namely health risks (sig. 0.001 ) and crime rates (sig. 0.006). Men, on the other hand, accessed more information 
on some positive attributes of migration, namely wages (sig. 0.011) and life satisfaction (sig. 0.0001) than women.

In the complex choice (with unlimited access to data), gender patterns of information search were essentially the same as in the binary choice. Women again requested more information on selected negative attributes of migration than men, namely on health risks (Mann-Whitney U-test sig. 0.0001) and crime (sig. 0.0001). Men, on the other hand, continued requesting more about life satisfaction (sig. 0.001).

The dominant attributes (wages and living costs) and migration attributes with higher degree of uncertainty (language difficulty, health risks, crime rate) appeared to be important in the binary choice, where the amount of available information was limited to $50 \%$ and country names were not revealed to the participants (Table 2, trials i - iv). In the complex choice condition, all information was available and country names were revealed to the participants. In general, attribute rankings in trials $1-4$ in the complex choice were fairly similar to those in trials iiv in the binary choice, for both gender and migrants/non-migrants. Dominant attributes (wages and living costs) retained their high decision weights, but revealing country names slightly impacted the decision weights of some non-dominant attributes (language and climate in particular). Participants could rely on their actual knowledge and/or country image, and substitute some missing information from country names and images. Few participants, for example, were concerned with issues of freedom \& security and health risks in developed countries. We assume that the lack of request for information exemplifies the substitution of positive information for a missing one (García-
Retamero, Rieskamp, 2008, 2009). For some less-developed countries little or no information was demanded and these countries were consistently assigned low ranking. In such cases, missing information was surrogated with negative one.

As for the migration experience, non-migrants sought more information than migrants on language difficulty (MannWhitney U-test sig. 0.003), wage levels (sig. 0.048) and living costs (sig. 0.058) in the binary choice. Migrants demanded more information on climate (sig. 0.024) and life satisfaction (sig. 0.018) than non-migrants.

Most of these patterns in information search were repeated in the complex choice condition as well. The non-migrants, for example, requested more information on wages and costs (Mann-Whitney U-test sig. 0.014 and 0.002) and crime (sig. 0.042). The nonmigrants did not ask more about language than migrants in the complex choice - as the name of the country was provided in this condition and migrants and non-migrants could derive information on language difficulty from the country name.

\section{DISCUSSION}

We tried to examine some real-life complex decisions on economic issues in this study. Decisions, such as what financial product to purchase and/or which country to choose for migration, are fraught with high uncertainty about their outcomes. Participants may not always have the opportunity to practice such complex choices and reverse their potentially damaging outcomes.

We concentrated on the first judgmental phase of the decision making: pre-decisional information search for reaching a judgment on choice alternatives. The main result of 
the research is that both men/women and experts/non-experts did proceed similarly when searching for information on decision attributes. The findings show that the assumptions by the rational expectations theory on full use of information, unlimited processing capacity, and consistent preferences are hardly realistic for most participants. We found only few participants complying with the theory of rational expectation and using all available information. The use of heuristics in reducing the information burden was ubiquitous. The decision matrix had 120 information units in the financial product choice and 80 units in the migration destination choice. The amount of information needed to conclude the complex decision decreased significantly over four trials and converged to some 28-34 units in trial 4 in each decision tasks (Hypothesis 1 and 2).

Experts asked for less information than non-experts in each of the four trials, and the non-experts accounted for a more linear learning curve in the decision task on financial products. The participants' migrant experience played a role, since they asked for less information in the earlier trials as they could draw on their migration experiences and identify information relevant for migration better than non-migrants (Hypothesis 3).

Experts in financial products and participants with migration experience accounted for a more pronounced curvature of the learning curve. Expertise/experience was more important for learning than the gender. In the decision task on financial products, men seemed to use information more frugally than women, but this was related to higher percentages of men than women in the expert group in our sample (Hypothesis 4).

We examined high-consequence decisions on two very different subjects (financial prod- ucts versus international labor migration), and analyzed judgment formation under diverse types of choices (binary vs. complex choice, limited versus unlimited access to information). Considerable stability of preferences across diverse decision types of choices or task condition was found in the binary and the complex choices. With the ongoing trials the amount of requested information was decreasing, however the type of information required (dominant attributes) was not changing (Hypothesis 5).

As for the expectation that experts will assign different importance (decision weights) to particular attributes of alternatives compared to non-experts (Hypothesis 6), we found fewer differences than expected. In the financial products task, only one significant difference was found: participants with lower perceived expertise were more interested in risks related to the investment. Participants with migrant experience requested more information on climate and life satisfaction than non-migrants. The non-migrants sought more information than migrants on language difficulty, wage levels and living costs.

Information search patterns for two dominant attributes followed the logic of the 'advantage first' principle. Dominant attributes were coming in pairs in both decision tasks, where the first attribute was related to major advantages and the second one to major costs of the potential outcomes ('the advantage first' principle, Hypothesis 7).

Although not hypothesized, we found some differences between men and women in information search. These differences were related to the content of preferred attributes as well. In the decision task on financial products, for example, women accounted for lower expertise on financial products than men and surrogated this expertise with the name of 
the financial institution. In the decision task on migration, women were more anxious about health risks and crime rates than men, and migrants asked more questions on life satisfaction than non-migrants. We assume that information search patterns established for men/women and also migrants/non-migrants in our research correspond with the preferences expressed by the respective population groups in selected large-scale surveys in developed countries. These information search patterns may reflect a wish to reduce stress stemming from uncertainty (in case of information on living costs, health risks, and crime rate) and/or a need for reconfirming personal beliefs (e.g., that life satisfaction is higher abroad than home).

\section{CONCLUSION}

Better understanding of ways people adopt high-consequence decisions may help improve the quality of decision outcomes. Literature on financial investments highlights the importance of risk and return for making high-consequence decisions. Risk and return considerations (including annual, entry and exit fees) dominate decisions on purchase of financial products, but other considerations (optimal investment horizon, ready access to money and name of financial institutions) accounted for one third of the total decision weights in our research. We suggest that financial advisors and educators provide consumers with more knowledge on liquidity constraints and optimal time horizons for particular types of investments. Neoclassical theories of labor migration acknowledge the importance of monetary and non-monetary factors for making decisions on international labor migration (Sjaastad, 1962, p. 84). The non-monetary factors, how- ever, are rarely examined in the migration literature. This research confirmed the assumptions that wages and living costs indeed are dominant migration attributes, but it also found that non-monetary factors account for over half of the total decision weights. Job agencies and/or international employers offering jobs to prospective migrants may provide them with more balanced information on work and life conditions in the countries of destination.

Our research study had several important limitations. Members of the sample were young highly educated Slovaks and cannot be considered typical consumers and/or migrants. The sample structure did not allow for analyzing differences in complex decision-making stemming from age, education, culture and social status. Also, it is not clear, for instance, how far the major findings of the research study (importance of expertise, stability of preferences, 'the advantage first principle') can be extended to other highconsequence complex decisions on economic issues (e.g., deciding on private health insurance, establishing a business enterprise, buying a new house). Future research may address these limitations via designing decision tasks for population groups with more diverse age and education structure, and/or examining other types of the highconsequence decisions.

Received July 14, 2013

\section{REFERENCES}

BALÁŽ, V., 2012, Perceived and actual financial literacy, Ekonomický Časopis, 60, 681-97.

BETTMAN, J.R., LUCE, M.F., PAYNE, J.W., 1998, Constructive consumer choice processes. Journal of Consumer Research, 25, 187-217.

FREEDOM HOUSE, 2012, Freedom in the World 2012 . 
GARCÍA-RETAMERO, R., RIESKAMP, J., 2008 , Adaptive mechanisms for treating missing information: A simulation study. The Psychological Record, 58, 547-568.

GARCÍA-RETAMERO, R., RIESKAMP, J., 2009 Do people treat missing information adaptively when making inferences? The Quarterly Journal of Experimental Psychology, 62, 1991-2013.

HUBER, O., WIDER, R., HUBER, O.W., 1997, Active information search and complete information presentation in naturalistic risky decision tasks. Acta Psychologica, 95, 15-29.

HUBER, O., HUBER, O.W., BÄR, A.S., 2011 , Information search and mental representation in risky decision making: The advantages first principle. Journal of Behavioural Decision Making, 24, 223-448.

ILO, International Labour Office 2010, Global Wage Report 2010/2011. Wage policies in times of crisis. Geneva: International Labour Office.

KAHNEMAN, D., 2003, Maps of bounded rationality: A perspective on intuitive judgment and choice. In: T. Frangsmyr (Ed.), Les Prix Nobel: The Nobel Prizes 2002, (pp. 449-489). Stockholm: Nobel Found.

KIVETZ, R., SIMONSON, I., 2000, The effects of incomplete information on consumer choice. Journal of Marketing Research, 37, 427-448.

LiCHTENSTEIN, S., SLOVIC, P., 2006, The construction of preference. Cambridge, New York: Cambridge University Press.

MONTI, M., MARTIGNON, L., GIGERENZER, G., BERG, N., 2009, The impact of simplicity on financial decision-making. Proceedings of the $31 \mathrm{~s}$ Annual Conference of the Cognitive Science Society, 386, 1846-1851.

VON NEUMANN, J., MORGENSTERN, O., 1944, Theory of games and economic behavior. Princeton University Press.
PAYNE, J.W., 1976, Task complexity and contingent processing in decision making: An information search and protocol analysis. Organizational Behavior and Human Performance, 16, 366-387.

PAYNE, J.W., BETTMAN, J.R., JOHNSON, E.J., 1993, The adaptive decision maker. New York: Cambridge University Press.

REISEN, N., HOFFRAFE, U., MAST, F.W., 2008, Identifying decision strategies in a consumer choice situation. Judgment and Decision Making, 3, 641658 .

SIMON, H.A., 1978, Rationality as process and as product of thought. The American Economic Review, 68, 1-16.

SIMONSON, I., 2008, Will I like a "medium" pillow? Another look at constructed and inherent preferences. Journal of Consumer Psychology, 18, 155-169.

SJAASTAD, L.A., 1962, The costs and returns of human migration. Journal of Political Economy, 70, 80-93.

SLOVIC, P., 1995, The construction of preference. American Psychologist, 50, 364-371.

STIGLER, G.J., 1961, The economics of information. Journal of Political Economy, 69, 213225.

UNODC, United Nations Office on Drugs and Crime 2011, Global Study on Homicide. Trends, Context, Data. Vienna: UNODC.

WARREN, C., McGRAW, A.P., van BOVEN, L., 2011, Values and preferences: Defining preference construction. Wiley Interdisciplinary Reviews: Cognitive Science, 2, 193-205.

WHITE, A., 2007, A global projection of subjective well-being: A challenge to positive pychology? Psychtalk, 56, 17-20.

WHO, World Health Organisation 2012, International travel and health 2012 Edition. Geneva: World Health Organisation. 


\section{APPENDIX}

Recording sheets used by researcher

\section{Choice of financial product}

Table A. Example of binary choice: participants can request up to $50 \%$ of the available information

\begin{tabular}{|l|c|c|c|c|c|c|c|c|}
\hline Variant 1 & Risk & Return & Entry Fee & $\begin{array}{c}\text { Optimal } \\
\text { Investment } \\
\text { Horizon }\end{array}$ & $\begin{array}{c}\text { Access to } \\
\text { Money }\end{array}$ & $\begin{array}{c}\text { Annual } \\
\text { Fee }\end{array}$ & $\begin{array}{c}\text { Exit } \\
\text { Fee }\end{array}$ & $\begin{array}{c}\text { Bank } \\
\text { Name }\end{array}$ \\
\hline Investment 1 & very low & comparable to TD & $0.20 \%$ & in 1 year & in 1 week & $0.10 \%$ & none & $\begin{array}{c}\text { Slov. } \\
\text { sporitel'na }\end{array}$ \\
\hline Investment 2 & none & as in TD & $0.00 \%$ & in 1 year & in 1 year & $0.00 \%$ & none & $\begin{array}{c}\text { vúB } \\
\text { banka }\end{array}$ \\
\hline
\end{tabular}

Table B. Example of complex choice: unlimited amount of information can be requested

\begin{tabular}{|c|c|c|c|c|c|c|c|c|c|}
\hline & Trial 1 & Risk & Return & $\begin{array}{l}\text { Entry } \\
\text { Fee }\end{array}$ & $\begin{array}{c}\text { Optimal } \\
\text { Investment } \\
\text { Horizon }\end{array}$ & $\begin{array}{l}\text { Access } \\
\text { to } \\
\text { Money }\end{array}$ & $\begin{array}{c}\text { Annual } \\
\text { Fee }\end{array}$ & $\begin{array}{l}\text { Exit } \\
\text { Fee }\end{array}$ & $\begin{array}{l}\text { Bank } \\
\text { Name }\end{array}$ \\
\hline A & $\begin{array}{l}\text { Money Market } \\
\text { Fund } 1\end{array}$ & very low & $\begin{array}{c}\text { comparable } \\
\text { to TD }\end{array}$ & $0.20 \%$ & in 1 year & $\begin{array}{c}\text { in } 1 \\
\text { week }\end{array}$ & $0.10 \%$ & nil & $\begin{array}{c}\text { Slov. } \\
\text { sporitel'ňa }\end{array}$ \\
\hline B & $\begin{array}{l}\text { Money Market } \\
\text { Fund } 2\end{array}$ & very low & $\begin{array}{l}\text { comparable } \\
\text { to TD }\end{array}$ & $0.10 \%$ & in 1 year & $\begin{array}{l}\text { in } 10 \\
\text { days }\end{array}$ & $0.20 \%$ & nil & OTP banka \\
\hline $\mathrm{C}$ & $\begin{array}{l}\text { Money Market } \\
\text { Fund } 3\end{array}$ & very low & $\begin{array}{c}\text { comparable } \\
\text { to TD }\end{array}$ & $0.00 \%$ & in 1 year & $\begin{array}{c}\text { in } 1 \\
\text { week }\end{array}$ & $0.10 \%$ & nil & Zuneda \\
\hline D & Term Deposit 1 & none & $\begin{array}{l}\text { current yield } \\
\text { on TD }\end{array}$ & $0.00 \%$ & in 1 year & $\begin{array}{l}\text { after } 1 \\
\text { year }\end{array}$ & $0.00 \%$ & nil & VÚB banka \\
\hline $\mathbf{E}$ & Term Deposit 2 & none & $\begin{array}{c}\text { current yield } \\
\text { on TD } \\
+0.2 \% \\
\end{array}$ & $0.00 \%$ & in 1 year & $\begin{array}{l}\text { after } 1 \\
\text { year }\end{array}$ & $0.00 \%$ & nil & Dexia \\
\hline F & Term Deposit 3 & none & $\begin{array}{c}\text { current yield } \\
\text { on TD } \\
+0.4 \% \\
\end{array}$ & $0.00 \%$ & in 1 year & $\begin{array}{l}\text { after } 1 \\
\text { year }\end{array}$ & $0.00 \%$ & nil & Zuneda \\
\hline G & Stock Fund 1 & $\begin{array}{l}\text { high, potential } \\
\text { loss up to } 35 \%\end{array}$ & $\begin{array}{c}2 \text { - } 4 \text { times } \\
\text { return on } \\
\text { TD }\end{array}$ & $2.50 \%$ & over 10 years & $\begin{array}{l}\text { in } 10 \\
\text { days }\end{array}$ & $2.50 \%$ & $1.00 \%$ & $\begin{array}{c}\text { IAD } \\
\text { Investments }\end{array}$ \\
\hline H & Stock Fund 2 & $\begin{array}{l}\text { high, potential } \\
\text { loss up to } 25 \%\end{array}$ & $\begin{array}{c}2 \text { - } 5 \text { times } \\
\text { return on } \\
\text { TD }\end{array}$ & $2.00 \%$ & over 10 years & $\begin{array}{c}\text { in } 1 \\
\text { week }\end{array}$ & $1.20 \%$ & nil & $\begin{array}{c}\text { Delia- } \\
\text { Cagnotte }\end{array}$ \\
\hline
\end{tabular}

Table B continues 
Table B (continued)

\begin{tabular}{|c|c|c|c|c|c|c|c|c|c|}
\hline I & Stock Fund 3 & $\begin{array}{l}\text { high, potential } \\
\text { loss up to } 35 \%\end{array}$ & $\begin{array}{l}3-6 \text { times } \\
\text { return on } \\
\text { TD }\end{array}$ & $3.00 \%$ & over 10 years & $\begin{array}{c}\text { in } 1 \\
\text { week }\end{array}$ & $2.30 \%$ & $2.00 \%$ & VÚB banka \\
\hline $\mathbf{J}$ & $\begin{array}{l}\text { Investment Life } \\
\text { Insurance } 1\end{array}$ & $\begin{array}{l}\text { low, moderate but } \\
\text { sure return }\end{array}$ & $\begin{array}{c}\text { comparable } \\
\text { to } \mathrm{TD}+ \\
1.5 \% \\
\end{array}$ & $3.50 \%$ & min. 10 years & $\begin{array}{l}\text { after } 2 \\
\text { years }\end{array}$ & $4.00 \%$ & nil & Habitatpro \\
\hline K & $\begin{array}{l}\text { Investment Life } \\
\text { Insurance } 2\end{array}$ & $\begin{array}{l}\text { medium, no return } \\
\text { guaranteed }\end{array}$ & $\begin{array}{c}\text { comparable } \\
\text { to } \mathrm{TD}+ \\
4.0 \% \\
\end{array}$ & $4.90 \%$ & min. 10 years & $\begin{array}{l}\text { after } 2 \\
\text { years }\end{array}$ & $5.00 \%$ & nil & Kooperativa \\
\hline $\mathbf{L}$ & $\begin{array}{l}\text { Investment Life } \\
\text { Insurance } 3\end{array}$ & $\begin{array}{l}\text { medium/low, low } \\
\text { return possible }\end{array}$ & $\begin{array}{c}\text { comparable } \\
\text { to } \mathrm{TD}+ \\
3.1 \% \\
\end{array}$ & $4.40 \%$ & min. 10 years & $\begin{array}{l}\text { after } 2 \\
\text { years }\end{array}$ & $4.70 \%$ & nil & $\begin{array}{c}\text { Victoria } \\
\text { Volksbank }\end{array}$ \\
\hline M & Pension Fund 1 & $\begin{array}{l}\text { medium, no return } \\
\text { guaranteed }\end{array}$ & $\begin{array}{c}\text { as in } \mathrm{TD}+ \\
1.3 \%\end{array}$ & $0.00 \%$ & min. 15 years & $\begin{array}{l}\text { after } 10 \\
\text { years }\end{array}$ & $1.95 \%$ & nil & $\begin{array}{c}\text { ING } \\
\text { Sympatia }\end{array}$ \\
\hline $\mathbf{N}$ & Pension Fund 2 & $\begin{array}{c}\text { medium/low, low } \\
\text { or no return } \\
\text { possible }\end{array}$ & $\begin{array}{c}\text { comparable } \\
\text { to } \mathrm{TD}+ \\
1.8 \% \\
\end{array}$ & $0.00 \%$ & min. 15 years & $\begin{array}{l}\text { after } 10 \\
\text { years }\end{array}$ & $1.80 \%$ & $1.00 \%$ & AXA \\
\hline 0 & Pension Fund 3 & $\begin{array}{l}\text { medium, no return } \\
\text { guaranteed }\end{array}$ & $\begin{array}{c}\text { comparable } \\
\text { to } \mathrm{TD}+ \\
2.5 \%\end{array}$ & $0.00 \%$ & $\min .15$ years & $\begin{array}{l}\text { after } 10 \\
\text { years }\end{array}$ & $1.00 \%$ & nil & $\begin{array}{l}\text { Pontilia } \\
\text { Fortexa }\end{array}$ \\
\hline
\end{tabular}

Notes: $\mathrm{TD}=$ term deposit in bank

\section{Choice of potential migration destination}

Table A. Example of binary choice: participants can request up to $50 \%$ of the available information

\begin{tabular}{|l|c|c|c|c|c|c|c|c|}
\hline Trial 1 & $\begin{array}{c}\text { Health } \\
\text { risk }\end{array}$ & Language & $\begin{array}{c}\text { Freedom and } \\
\text { security }\end{array}$ & $\begin{array}{c}\text { Wage } \\
\text { (EUR) }\end{array}$ & $\begin{array}{c}\text { Crime } \\
\text { rate }\end{array}$ & $\begin{array}{c}\text { Life } \\
\text { satisfaction }\end{array}$ & $\begin{array}{c}\text { Minimal } \\
\text { monthly } \\
\text { living costs } \\
\text { (EUR) }\end{array}$ \\
\hline $\begin{array}{l}\text { Country } \\
\mathbf{1}\end{array}$ & Low & Very easy & Very high & 1000 & Low & Medium-low & Mild & 330 \\
\hline $\begin{array}{l}\text { Country } \\
\mathbf{2}\end{array}$ & Low & easy & Very high & 1500 & $\begin{array}{c}\text { Very } \\
\text { low }\end{array}$ & High & Mild & 450 \\
\hline
\end{tabular}


Table B. Example of complex choice: unlimited amount of information can be requested

\begin{tabular}{|c|c|c|c|c|c|c|c|c|c|c|c|}
\hline Trial 2 & $\begin{array}{c}\text { Health } \\
\text { risk }\end{array}$ & Language & $\begin{array}{l}\text { Freedom } \\
\text { \& security }\end{array}$ & $\begin{array}{l}\text { Wage } \\
\text { (EUR) }\end{array}$ & $\begin{array}{c}\text { Crime } \\
\text { rate }\end{array}$ & $\begin{array}{c}\text { Life } \\
\text { satisfac- } \\
\text { tion }\end{array}$ & Climate & \begin{tabular}{|c} 
Minimal \\
monthly \\
living costs \\
(EUR)
\end{tabular} & $\begin{array}{c}\text { Rank- } \\
\text { ing } \\
1-10\end{array}$ & $\begin{array}{c}\text { Knowl- } \\
\text { edge } \\
1-10\end{array}$ & $\begin{array}{c}\text { Image } \\
1-10\end{array}$ \\
\hline Taiwan & $\begin{array}{c}\text { Medium- } \\
\text { low }\end{array}$ & Chinese & High & 1850 & Low & High & $\begin{array}{c}\text { Hot } \\
\text { humid }\end{array}$ & 600 & & & \\
\hline $\begin{array}{l}\text { Czech } \\
\text { Rep. }\end{array}$ & Low & Czech & Very high & 1000 & Low & $\begin{array}{c}\text { Medium- } \\
\text { low }\end{array}$ & Mild & 330 & & & \\
\hline Argentina & $\begin{array}{c}\text { Medium- } \\
\text { high }\end{array}$ & Spanish & high & 1450 & $\begin{array}{c}\text { Medium- } \\
\text { high }\end{array}$ & High & $\begin{array}{c}\text { Mediterra } \\
\text { nean }\end{array}$ & 380 & & & \\
\hline Iran & $\begin{array}{c}\text { Medium- } \\
\text { high }\end{array}$ & Farsi & Very low & 1600 & $\begin{array}{c}\text { Medium- } \\
\text { low }\end{array}$ & $\begin{array}{l}\text { Medium- } \\
\text { low }\end{array}$ & Hot dry & 300 & & & \\
\hline Vietnam & High & $\begin{array}{l}\text { Vietnam- } \\
\text { ese }\end{array}$ & Very low & 1500 & Low & $\begin{array}{l}\text { Medium- } \\
\text { high }\end{array}$ & $\begin{array}{c}\text { Hot } \\
\text { humid }\end{array}$ & 100 & & & \\
\hline Britain & Low & English & Very high & 1800 & Low & High & Mild & 1000 & & & \\
\hline Honduras & High & Spanish & $\begin{array}{l}\text { Medium- } \\
\text { low }\end{array}$ & 1800 & $\begin{array}{l}\text { Very } \\
\text { high }\end{array}$ & High & $\begin{array}{c}\text { Hot } \\
\text { humid }\end{array}$ & 200 & & & \\
\hline Poland & $\begin{array}{c}\text { Medium- } \\
\text { Low }\end{array}$ & Polish & Very high & 1100 & Low & $\begin{array}{l}\text { Medium- } \\
\text { low }\end{array}$ & Mild & 350 & & & \\
\hline Finland & Low & Finnish & Very high & 2500 & $\begin{array}{c}\text { Medium- } \\
\text { low }\end{array}$ & Very high & Mild cold & 1500 & & & \\
\hline Oman & $\begin{array}{c}\text { Medium- } \\
\text { low }\end{array}$ & Arabic & Low & 1800 & $\begin{array}{l}\text { Very } \\
\text { low }\end{array}$ & High & Hot dry & 600 & & & \\
\hline
\end{tabular}

\title{
SKÚSENOSŤ A VZORY VYHLADÁVANIAINFORMÁCIÍ VKOMPLEXNOM ROZHODOVANÍ
}

\author{
V. B a 1 á ž, V. B a č o vá, P. Š k r i n i a r
}

Súhrn: Výskumná štúdia sa zamerala na problematiku vzorov vyhl'adávania informácií a spôsoby, ktoré jednotlivci používajú, aby znížili zložitost' rozhodovania a posúdili alternatívy v podmienkach neúplných informácií. Ciel'om bolo zistit', či a ako sa participanti s finančnou a migračnou skúsenost'ou líšia od participantov bez tejto skúsenosti v získavaní a zorad'ovaní informácií pred vol’bou finančných produktov a destinácie pracovnej migrácie. Autori skúmali množstvo a obsah informácií, ktoré participanti požadovali v modelových úlohách rozhodovania. Vnímaná expertnost' a skúsenost' sa javila významnejšia pre učenie a redukovanie informačnej zát'aže než rod. Zistila sa značná stabilita preferencií v rozhodovacích úlohách $\mathrm{s}$ obmedzeným a neobmedzeným prístupom k informáciám. Vo vyhl'adávaní informácií pred vol'bou dominantné atribúty boli vyhl'adávané $\mathrm{v}$ pároch, pričom prvý atribút sa týkal hlavných výhod a druhý hlavných nákladov potenciálnych výsledkov rozhodnutia, rovnako v rozhodovacej úlohe o financiách aj o migrácii. 